$\mathrm{Oz}$

Volume 34

Article 11

$1-1-2012$

\title{
The Public Work: Redefining the Standard for an Urban Society
}

Timothy de Noble

Follow this and additional works at: https://newprairiepress.org/oz

(c) (1) (ब)

This work is licensed under a Creative Commons Attribution-Noncommercial-No Derivative Works 4.0 License.

\section{Recommended Citation}

de Noble, Timothy (2012) "The Public Work: Redefining the Standard for an Urban Society," Oz: Vol. 34. https://doi.org/10.4148/2378-5853.1507

This Article is brought to you for free and open access by New Prairie Press. It has been accepted for inclusion in Oz by an authorized administrator of New Prairie Press. For more information, please contact cads@k-state.edu. 


\title{
The Public Work:
}

\section{Redefining the Standard for an Urban Society}

\author{
Timothy de Noble
}

Acommonlament of our era is that our cities are undefined, usually in reference to the lack of an easily circumscribed boundary. The once defined, bounded, defensible city is committed to history, undone by modern weaponry, howitzers, bombers, automobiles and their highways, and the interconnectivity of cyberspace. Today our cities are symbolized less by horizontal boundaries or vertical extremes than by the quality of their construction and the quality of life directly related to the quality of their public realms. This is not a geographical argument, nor is it one dependent on the size or wealth of a city. Quality is not a regional concept, though there may be geographically specific representations and material distinctions. Smaller cities and towns are as needful of a vital urban public realm as are the larger metropolises of the world.

The material, rather than the spatial aspects of the public realm, are the focus of this paper. The public works (once termed; internal improvements) or public infrastructure of our cities, are perhaps best defined as "the connective tissue that knits people, places, social institutions, and the natural environment into coherent urban relationships. It is shorthand for the structural underpinnings of the public realm."'

Expedient, rapid-fire, off-the-shelf, acontextual and ill-conceived solutions have become the norm for postwar America's urban infrastructure needs. ${ }^{2}$ An inexhaustible list of factors might include the shift from public on housing needs, transportation demands-particularly the non-urban interstate highway system - and an exponential dilution of urban resources due to growth and sprawl. Additionally, there is a lack of concern for the public realm seemingly coupled with our increased dependence upon non-social technologies, television, telecommunications, and the automobile. Sadly, we seem to discount the relationship between the quality of our physical environment and the quality of our social interactions.

A public work is required and has the opportunity to be understood at multiple levels: functional, social and representational. This is not a call for the grand projet or for the fallacy of the "silver bullet." ${ }^{3}$ Nor is this a nostalgiainduced plea for a new City Beautiful Movement-though we could do worse- or for us to sprinkle vacuous monuments, shrines and artists' installations throughout our cities. It is not an aesthetic vs. practical argument. It is a both/and appeal. We can no longer consider any public work solely as a pragmatic solution to a physical or programmatic need. This is an argument against the potential of double jeopardy inherent in the ill-conceived, single-use, fiscally expedient public work.

History provides us with an abundance of public works embodying the hopes and ideals of their respective urban societies while addressing functional necessity. The following historic examples illustrate the capacity of, and potential for definition inherent in our public works.

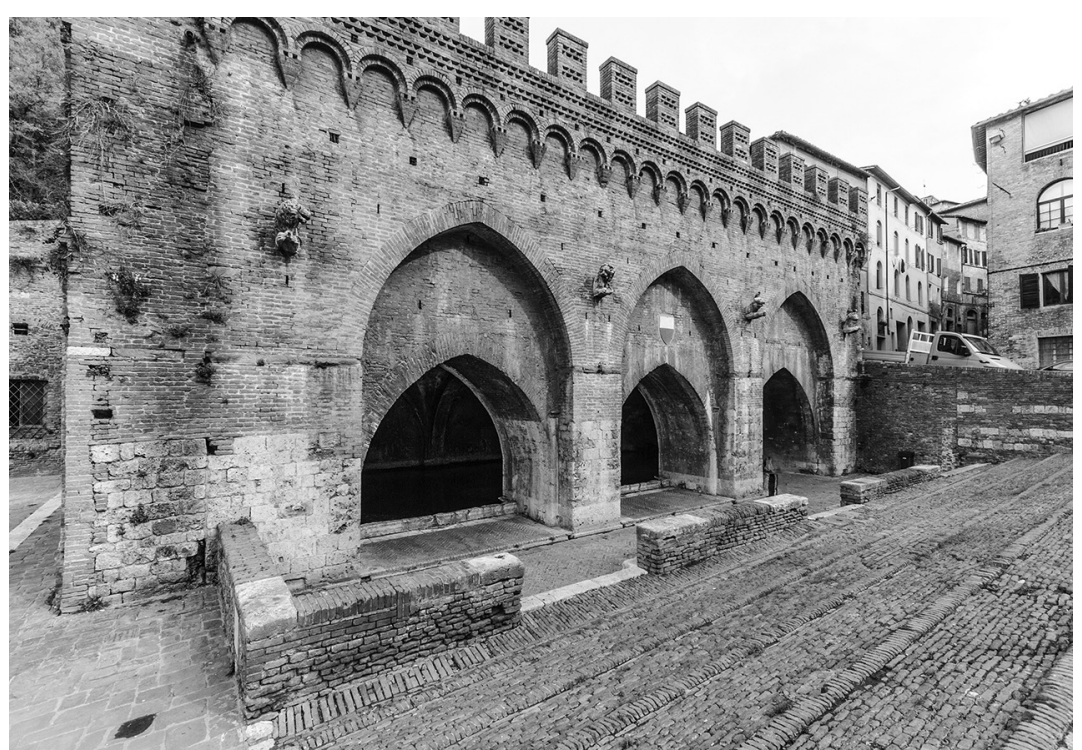

Fontebranda, Siena, Italy

Siena, Italy, is a well-known and wellloved city in Tuscany. The world's appreciation of this city stems from its apparent quality of life, its rich history, and the quality of its seemingly homogeneous brick and terracotta urban fabric and architecture. The monuments of the Campo, the Palazzo Publico and the Duomo define the city to the visitor and are sources of great prode to the Sienese. Lessknown outsiders are its historic, symbiotic infrastructure systems, streets, markets, tribunals, and particularly its water system. As a hill town, water is its most precious and difficult to obtain resource. Without it, any thought of inhabiting the hill, no matter how extreme the defensive needs, is impossible. The engineers of Siena, particularly Francesco Di Giorgio and Taccola (among the most important in history) were largely concerned with the conveyance, storage and protection of water. The results of these engineers' efforts led Emperor Charles V to remark that Siena is as beautiful below the ground as it is above. ${ }^{4}$ Admittedly much of the aqueduct (bottini) system remains underground, out of sight and out of mind of the citizenry. At its emergent points, its confluence with the public realm, we are presented with a spatial and social experience as well as a celebration: an appreciation of a technological solution to pragmatic necessity. Perhaps the best examples are the Fontebranda, built in the thirteenth century, an important, though local, fountain serving a district of the city, and the Fonte Gaia, located in the main square of the city, the Campo. These two fountains exemplify the primary criteria for the public work and serve to develop subsets of these criteria. 


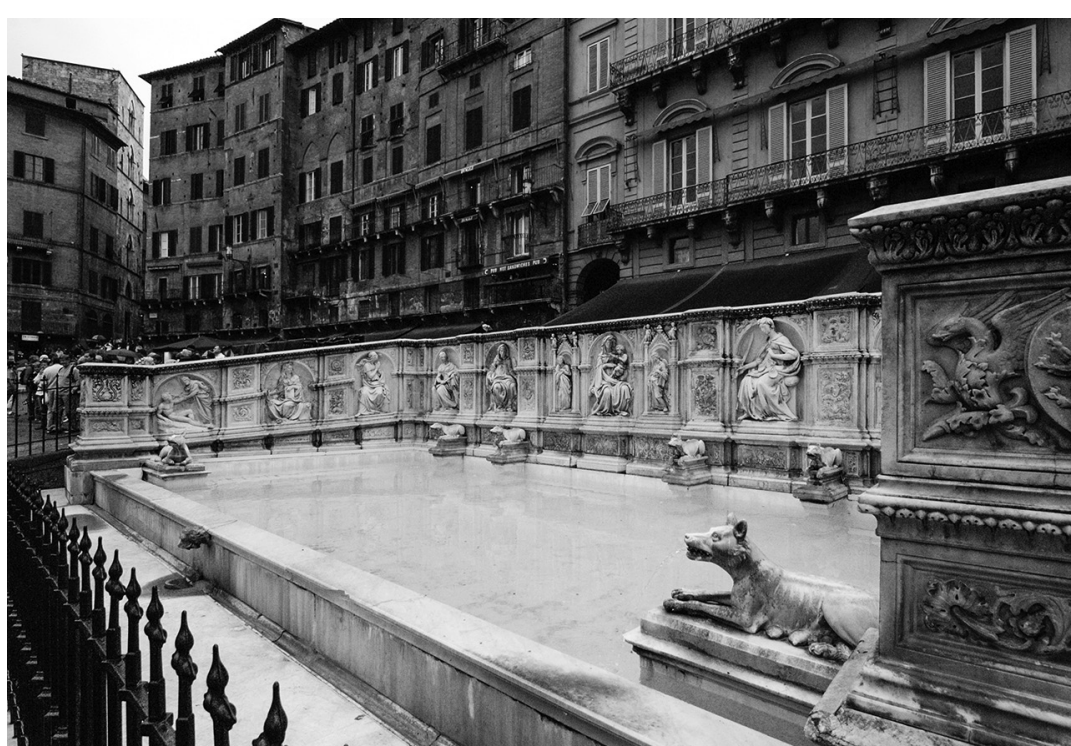

Fonte Gaia, Siena, Italy

In comparison to the Fonte Gaia, the Fontebranda is a utilitarian fountain. It supplied water to the district, which in course had to be carried by individuals to the households of the district. It was designed to include a series of basins serving different functions and levels of relative water purity, including a catch basin for gray water. Fontebranda served as a medieval laundry mat, animal market, fish tank, and watering hole for horses, and ultimately as a local gathering place. It was also built as a mini-fortress for its defense in times of siege. Most significantly, though a public device, this infrastructure element cum artifact is a symbol, a representation of its neighborhood. The citizenry has appropriated it as their own. Perhaps it is as inseparable from these people as the Duomo or the Palazzo Publico are to the citizenry of the cumulative

city. The appropriation of this urban artifact ${ }^{5}$ by the populace is not solely dependent on its functional role, nor is it wholly dependent on it's gathering or social capacity. Its most significant role is in the association of meaning, of representation dependent on the quality of its construction, its materials, craft, and its obvious dependence upon the typical masonry construction of Siena and upon its history. It is timeless, permanent.

Fonte Gaia, built in 1343 is obviously more 'precious' in material, detail, and indeed, location. It too is representative, functional, and social. In the relative hierarchy of the city-i.e. the city to the neighborhood, the whole to the part-it is more significant, precious, and reflective of a greater entity and, consequently, this hierarchy is reflected in the high that ever-elusive 'Good Government' Too often our infrastructure needs quality of its craft and materials. The primacy of purpose is shifted from utility to representation. "The Fonte Gaia was both a celebration of Siena's past and contemporary glories, and a didactic monument, designed to instruct the Sienese in the obligations of citizenship. It was, like Lorenzetti's frescoes (The Allegories of Good and Bad Government), an imaginative, visual representation of the whole complex of interacting creative forces which the Sienese believed went into the making of the city, a blending of material and spiritual to produce prosperity, justice and of which the whole Campo is a celebration."' Like Fonte Branda, it is timeless, permanent.

ridors, not on ceremonial routes. It is incongruous, demeaning, scale-less, and oppressive in the Florentine summer heat. Perhaps most disturbing is its obvious impermanence.

Permanence is a difficult concept in discussion of the continuing city. When Augustus Caesar said, "I found Rome built of bricks; Ileave her clothed in marble," ${ }^{, 8}$ he referenced degrees and qualities of permanence. There are three degrees of permanence. The first and most obvious degree is material permanence, the relative ability of a material to resist forces of nature and of use or abuse over time; durability relative to erosion, decay, cycles, use, or vandalism. Allowing for climatic differences, concrete is more durable than brick, which is in turn more durable than wood, which is more durable than "Dryvit" and so on.

ting these fountain trates the concept of hierarchy in our urban infrastructure. Not all public works are or should be equal. Not all serve the entire population. ${ }^{7}$ Some are local, less important in the larger context but significant at a local level. are addressed without respect to their relative urban hierarchy, without a sense of propriety nor of urban decorum. For example, the Via dei Servi, the very important street connecting two of Florence's urban monuments, the Duomo and the Piazza Santissima Annuziata, was recently paved in asphalt. The street, primarily pedestrian with minimal one-way traffic, has always been paved in stone. Asphalt, in the center of Florence should be used on the Viale and other major vehicular cor-
The second degree of permanence is related to an understanding, appreciation, awe, perhaps even a reverence for the act of making or fabrication. We understand material quality and we comprehend and appreciate craft. ${ }^{9} \mathrm{We}$ respect the act of making, even when we do not always understand the process. Students marvel at the masonry Poikile wall at Hadrian's Villa, "What an incredible wall! What are those holes? Why is there a change in the brick pattern?" And finally, "Why don't we do this today?" The artist Chuck Close was asked if his portraits would command any interest one hundred years from now to which he replied, "Absolutely! The craft aspect of my work gives it a built-in antique value. 
In the future, museums won't throw my paintings away, if only because they look like they took so long to make." ${ }^{10}$ What happened to sidewalks in America? What became of the fabricator's seal, placed every so often along a concrete walk indicating who made the walk and when? We have exorcised the maker from the product, preferring product over process rather than allowing simultaneous appreciation of both.

The third degree of permanence is more elusive. This notion of permanence is largely dependent upon Aldo Rossi's summation of the topic in his seminal text, The Architecture of the City. ${ }^{11}$ One explanation is that, "permanences are a past we are still experiencing." Another might be to consider those things which the city has appropriated as its own: the monument. "A monument's persistence or permanence is a result of its capacity to constitute the city, its history and art, its being and memory." It is important to note that permanence is not dependent upon function. Function is impermanent, embattled by growth, undermined by technological advancement and changing perceptions of need and utility. Typically it is difficult to attain this level of permanence without achieving the other two. Perhaps, more accurately, all levels of permanence are interdependent when maintenance is added into the equa-

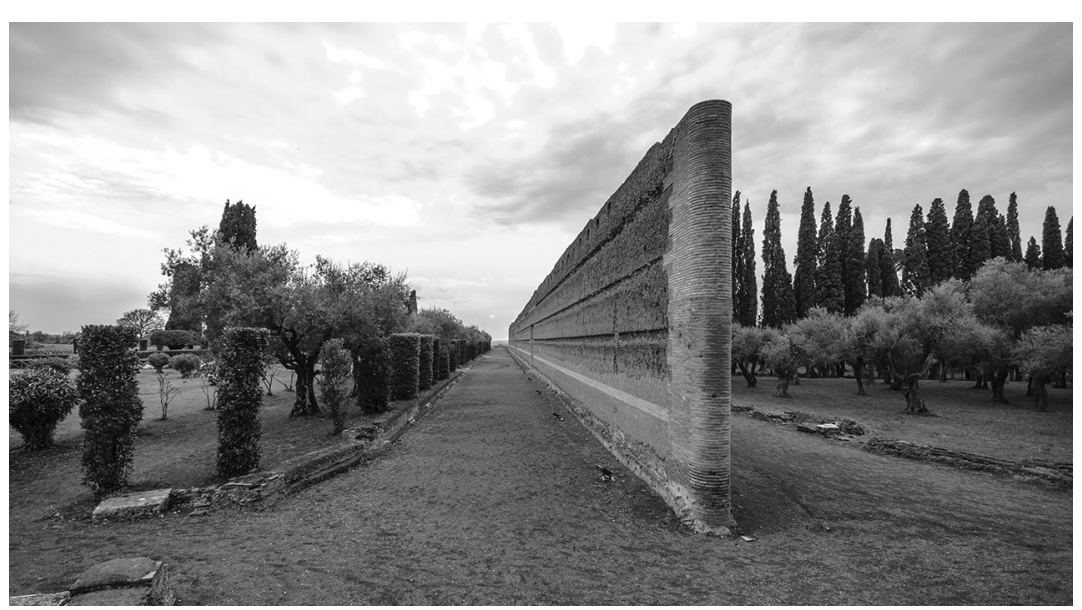

tion. Certain structures or monuments have become important enough symbolically that increased attention and continual maintenance overcomes shortcomings in the first two degrees of permanence.

The Water Works of Philadelphia were built at public expense between 1799 and 1822, by Benjamin Latrobe and later by Frederick Graff, to supply the city with water from the Schuylkill River. ${ }^{12}$ The project consists of a dam, pump-house, reservoir, superintendent's lodge, and pavilions. As in the previous Sienese examples, this public infrastructure project meets the multiple criteria set forth earlier: utility, social, and representational. When completed the Water Works were, though in the boundaries of Penn's original projection of the city, well removed from its built areas. It became a retreat, its pavilions gathering places for socials, picnics, and watching rowing along the river. Originally a semi-urban park, it was eventually incorporated into the great Fairmont Park System and subsumed by Greater Philadelphia. Like the Fonte Gaia, the Water Works has become an enduring representation of the city of Philadelphia. Because of its peripheral location, visible to the commuters of the "Main Line" it is the first evidence of the "original" city and is a commentary upon it. It is a precinct of sorts, its retaining walls along the Schuylkill

Poikile wall at Hadrian's Villa, Tivoli, Italy like those of the Acropolis in Athens, its pavilions like so many temples. The Water Works are not merely a fine example of Greek Revival architecture, but are understood as an ideal or at least a representation of an ideal for the City of Philadelphia. This representation has long outlived the original functional premise. Though the works no longer supply water to the city they continue to serve as a gathering, social place. Admittedly they have suffered the same vicissitudes of attention that many of our public urban artifacts have suffered in this century. However, their enduring quality, their permanence will very likely continue to revive them. They are "propelling" elements, not "pathological," in that they are at once restoring and restorable.

Rather than concentrate solely on projects associated with water let us look at a more "pedestrian" example: the walkways at the University of Arkansas. Since 1875 every graduate-more than 100,000 so far-has had his or her name inscribed in the concrete walkways of the campus. There are nearly five miles of names around the campus, once molded by pressing mounted type into fresh concrete and now etched by a patented sandblasting device, aptly named the "Sandhog" after the sports mascot. ${ }^{13}$ This is a particularly significant example, albeit for a limited populace as it is not dependent upon material preciousness or hierarchy, but is a celebration of an important feature of any city: the sidewalk. Concrete is often dismissed as an insidious material, referred to in derogatory terms and is in fact often associated with "jungle" in reference to the city. Often, other materials are used for walks and paved areas, sometimes inappropriately and without regard to local history, availability of materials and climatic conditions. Perhaps this explains why red brick paving is in vogue today in the United States, being placed on streets and sidewalks north and south, east and west. Concrete is not inherently "aesthetically challenged." The problem of concrete in the public realm is more a matter of hierarchy than of aesthetics; it is due to our failure to recognize the role and scope of certain infrastructure projects relative to the public realm.

Admittedly names do not make the most stimulating reading, though there are some entertaining names such as $\mathrm{L}$. Wanda Flurry and some notable ones such as J. William Fulbright. Yet it takes little imagination to see how this could become an interesting feature of cities, displaying famous quotations, history or biographies of great citizens. All of us have, at one time or another, found ourselves in a situation wishing we had something to read. Is there more value and potential interest in having the opportunity to read, for example, Lincoln's Second Inaugural Address while we wait for a bus rather than the ingredients of a discarded soda can or chip bag? "...With malice towards none, with charity for all, with firmness..." rather than, "Sodium...35mg, Total Carb..." Is this plea of layered use and relative permanence a ridiculous dream in a time of strained public finance, smaller government, and disregard for the public realm? How can it be? Our greatest eras of public works have been in response to crises. The infrastructures of our cities are in crisis now. We must reinvest in the public realm, simultaneously reevaluating and reinvigorating our fallow public works.

There is no posterity in expedience and no expedience in posterity. As long as we take a troubleshooting attitude towards infrastructure we will fail to capitalize on an opportunity to define our cities and positively affect the quality of our urban public life. The necessity of urban infrastructure is a potent physical resource. We should aim for the "Periclean" in defining our cities, striving for public works of permanent fiscal, social, and representational value. 


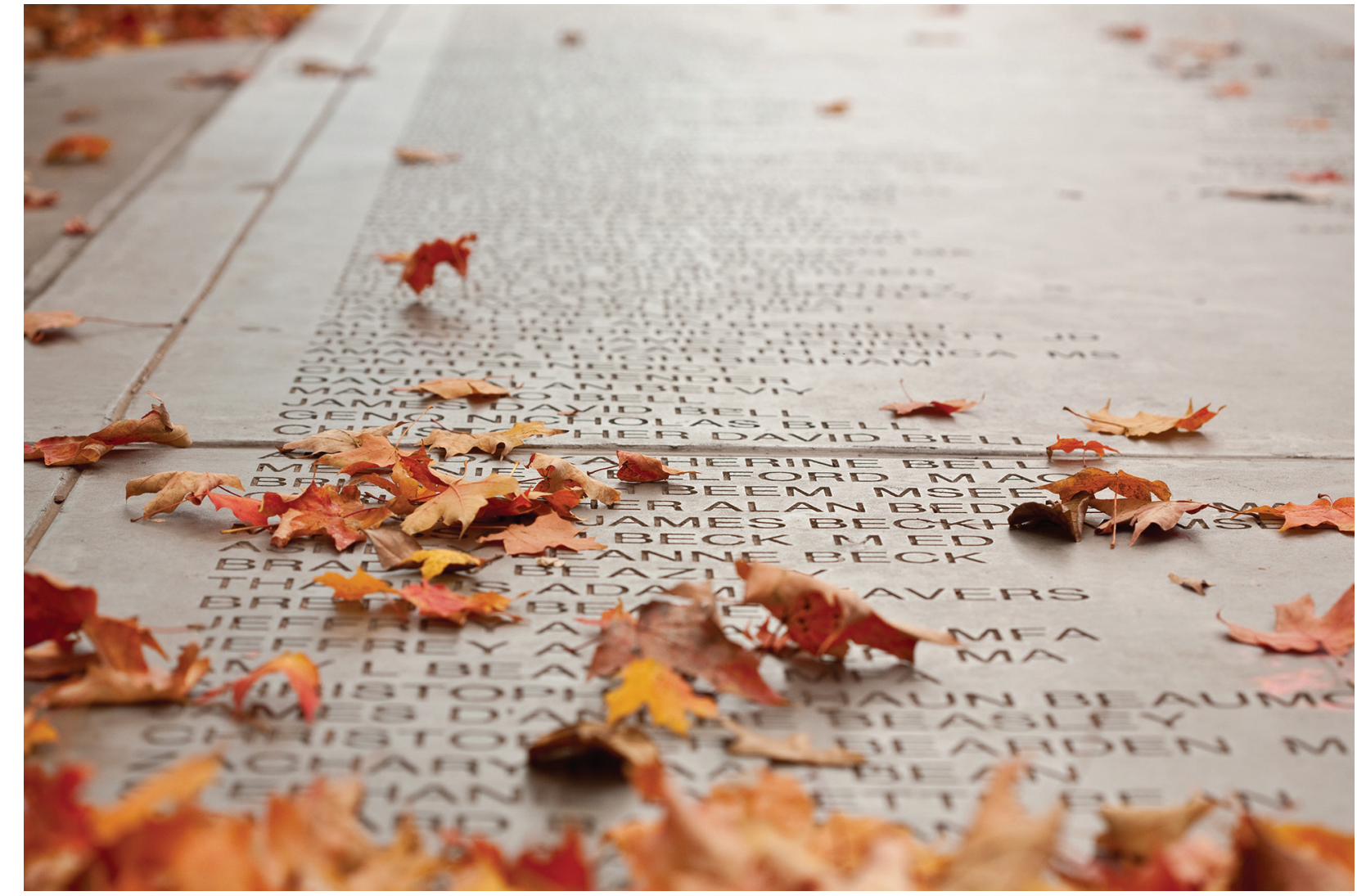

Graduate Walk, University of Arkansas. The pedestrian sidewalks have been inscribed with the names of every University of Arkansas Graduate

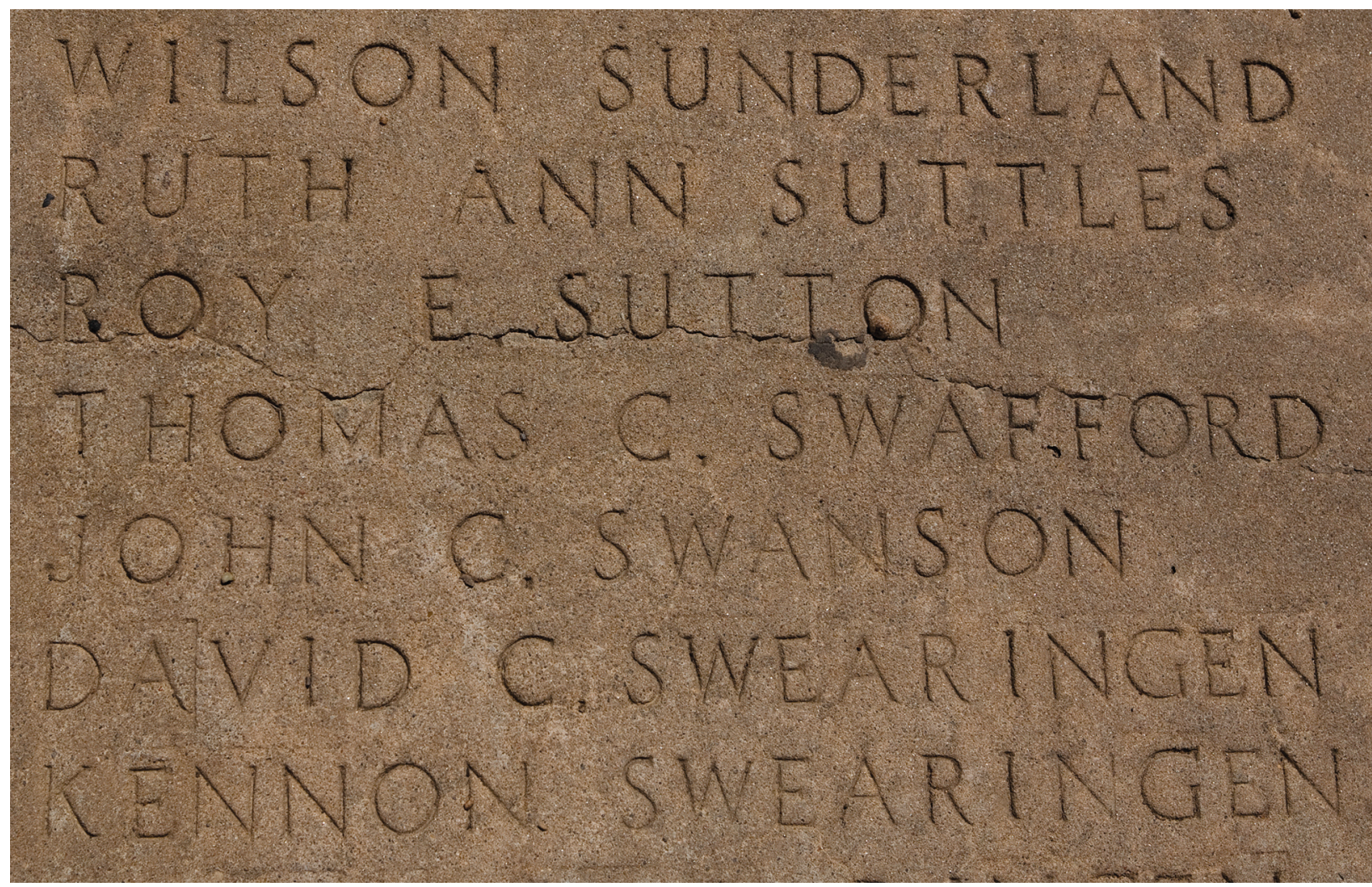

The original surface was created using mounted type to imprint the names into concrete

\section{Notes}

1. Muschamp, Herbert. "Two for the Roads: A Vision of Urban Design.” New York Times. Feb 13, 1994.

2. “...aesthetics is much less a function of money than of care, but care costs time. In a world where time means money, the less care put into buildings, deceptive appearance, from brick facings to cardboard structured doors, chipboard furniture to glossy fronts and cut-price rears, has become commonplace. We are rapidly building a world where deceptive appearance inadequately screens the primacy of profit over care. It is a world in which most people spend much of their daily lives and in which children grow up and learn-from their surroundings as well as from people-the values that will support them later in life." Day, Christopher. Places of the Soul. London, 1993. This observation is equally applicable to our urban infrastructure.

3. Palma, Dolores P. “Downtown Revitalization." Commentary. National Council for Urban Economic Development. Summer, 1995. 23-29.

4. Hook, Judith. Siena; A City and its History. London, 1979.97

5. Rossi, Aldo. The Architecture of the City. Cambridge, 1982. 55-57

6. Hook, 26

7. See the second stage of economy as defined by Vitruvius. The Ten Books of Architecture. Chapter 2.9

8. Suetonius, The Twelve Caesars. Augustus, sec 28 .

9. Vallhonrat, Carles. "Tectonics Consid ered; Between the Presence and the Absence of Artifice." Perspecta No. 24 1988. 128-130.

10. Soloman, Deborah. "Portraitist for the Information Age." The New York Times Magazine. February 1, 1998. 73

11. Rossi. 57-61

12. Armstrong, Ellis L. History of Public Works in the United States 1776-1976. Chicago, 1976. 217-218.

13. http://pigtrail.uark.edu/info/srwalk/

\section{Image Credits}

Fig 1-3: Ray Streeter

Fig 3-4: University Relations, University of Arkansas 